\title{
Managing human resources
}

\author{
By Judy Koor \\ Head of Reference Services \\ Ball State University
}

\section{A library conference with ACRL courses.}

B and the opportunity to offer ACRL continuing education courses at the local level prompted a twoday conference held at Ball State University on June 12-13, 1986. The conference, entitled "Managing Human Resources: Academic Library Perspectives" was co-sponsored by the Ball State University Libraries, the Ball State College of Business, and the Indiana ACRL Chapter. The seventythree participants came from Indiana, Ohio, Michigan, Illinois, and Kentucky.

The purpose of the conference was to offer professional development for academic librarians at the regional level, where cost would be affordable and transportation convenient. Plans were already underway at the Ball State University Libraries to have a one-day conference on a management theme when ACRL invited local libraries, ACRL chapters, and library associations to offer ACRL continuing education courses. Having ACRL continuing education courses in addition to speakers intrigued the conference planners. Sandy Donnelly, ACRL's continuing education program officer, was encouraging and enthusiastic about this innovative approach.

Selected Indiana academic librarians were surveyed for their interest in such a program and in possible course offerings. The response was positive with preferences indicated for courses on the management of human resources.

Adopting the concept of a regional conference where participants would come from Indiana and the surrounding states, the planning committee believed it was necessary to offer enough continuing education courses to accommodate at least 100 . Most of the ACRL continuing education courses are designed for twenty-five to thirty people, which meant offering four courses. Registrants were asked to indicate their first and second choices for these courses on the registration form. Shortly after the registration deadline on May 15, it was determined that the goal of 100 registrants would not be reached. The planning committee cancelled one of the courses with low enrollment.

Sponsorship by the Ball State College of Business and the Indiana ACRL Chapter promoted wider participation and helped defray costs, with each contributing money and participants. In addition, the Friends of Bracken Library and Baker \& Taylor, Inc. contributed substantially towards refreshments. The conference registration fee of $\$ 75$ included the speakers, the ACRL continuing education course with syllabus, three meals, and a wine and cheese reception.

The Conference began on Thursday, June 12 , with three presentations about different aspects of library management. Ron Leach, dean of libraries at Indiana State University and president of ALA's Library Administration and Management Association, spoke on "Preparing to Manage Tomorrow," giving an overview of what library managers are facing now and in the future. Julie Virgo, vice president of the Carroll Group, a management consulting firm, and president of the American Society for Information Science, spoke next on "Staff Costs in Management Decision Making." Her talk was a synopsis of how and why to do a cost analysis of staff time expenditures. Ray Montagno, associate 


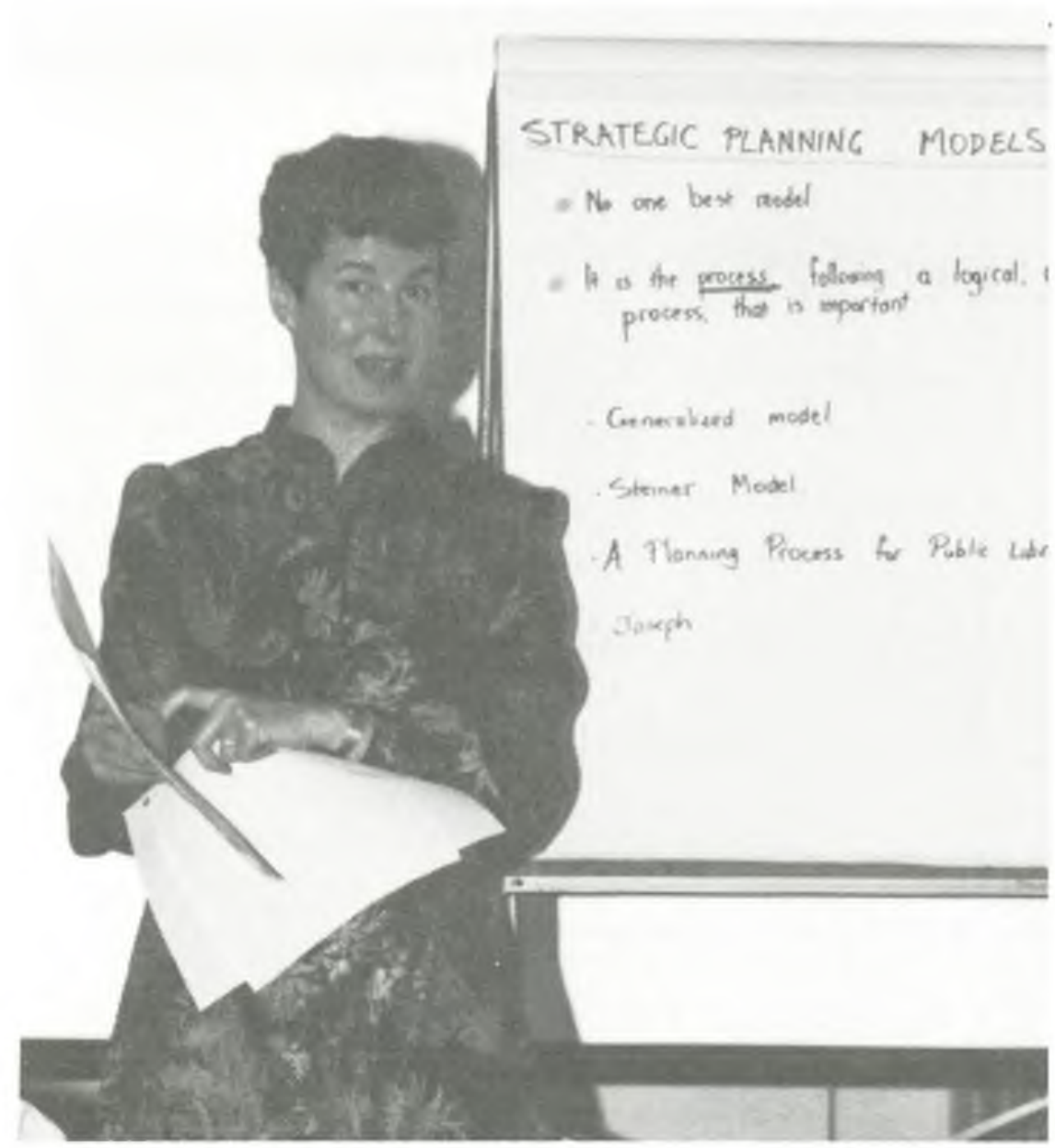

Julie Virgo conducting ACRL's CE 111, Principles of Strategic Planning.

professor of management at Ball State University and author of the Human Resources Information System Sourcebook, spoke on "Managing for Excellence in a Changing Environment." He covered the latest trends in human resources management and how they relate to entrepreneurship. That evening, Beverly Lynch, ALA president, gave the keynote address on "Human Resources: What Can
Managers Do?" She compared the manager's role today with the role managers had ten years ago when she spoke at Bracken Library's dedication.

The second day of the conference, three continuing education courses were taught concurrently. The courses and instructors were:

- CE 106, Performance Evaluation: A GoalsBased Approach; instructor: Lucy Cohen, University of Michigan;

- CE 111, Principles of Strategic Planning in the Library Environment; instructor: Julie Virgo, The Carroll Group;

- and CE 112,Improving Job Performance: Strategies for Supervisors; instructor: Maureen Sullivan, Yale University.

Evaluation information gathered from the participants indicated that the conference was a success. Comments indicated that the courses were very worthwhile and well-conducted. The majority responded that the theme and the continuing education courses were what most attracted them to the conference. Most of the participants indicated that they found it more advantageous to attend an ACRL continuing education course at a local meeting.

Two revisions considered for future conferences are holding the conference earlier in the spring and promoting it more among public librarians. The high degree of satisfaction expressed by the conference participants (including speakers and instructors) is a motivating factor for the Ball State University Libraries to hold this type of conference again.

\section{WHEN THE QUESTION IS SERVICE}

\section{THE $A N S W E R$ IS AMBASSADOR}

- FIRM ORDERS

- CONTINUATIONS

- APPROVAL PLANS

- BINDING SERVICES

- ON-LINE ORDERING

"serving college and university libraries for over 12 years" Ambassador Book Service, inc. 42 CHASNER STREET • HEMPSTEAD, NEW YORK 11550

toll free

$800 \cdot 431 \cdot 8913$ in New York call collect

(516) 489-4011 